\title{
Publisher Correction: Dietary thiols accelerate aging of C. elegans
}

Ivan Gusarov, Ilya Shamovsky, Bibhusita Pani, Laurent Gautier, Svetlana Eremina, Olga Katkova-Zhukotskaya, Alexander Mironov, Alexander A. Makarov \& Evgeny Nudler (B)

Correction to: Nature Communications https://doi.org/10.1038/s41467-021-24634-3, published online 15 July 2021.

The original version of the Supplementary Information associated with this Article included an incorrect Supplementary Data 1 file, which was a copy of Supplementary Data 3 file. The correct Supplementary Data 1 file has now been added to the HTML version of the article.

Published online: 06 December 2021

\section{Additional information}

Supplementary information The online version contains supplementary material available at https://doi.org/10.1038/s41467-021-27126-6.

(c) (i) Open Access This article is licensed under a Creative Commons Attribution 4.0 International License, which permits use, sharing, adaptation, distribution and reproduction in any medium or format, as long as you give appropriate credit to the original author(s) and the source, provide a link to the Creative Commons license, and indicate if changes were made. The images or other third party material in this article are included in the article's Creative Commons license, unless indicated otherwise in a credit line to the material. If material is not included in the article's Creative Commons license and your intended use is not permitted by statutory regulation or exceeds the permitted use, you will need to obtain permission directly from the copyright holder. To view a copy of this license, visit http://creativecommons.org/licenses/by/4.0/.

() The Author(s) 2021 